\title{
UIT DE GROTTEN VAN DE HEMELSE DRAAK: EEN TIANLONGSHAN BODHISATTVA IN HET RIJKSMUSEUM
}

\section{Sinds 1933 bezit het Rijksmuseum een zandstenen beeld van een} Bodhisattva uit Tianlongshan ( $a f b$. 1). Een willekeurige bezoeker raakt vrijwel onmiddellijk geïntrigeerd door de bijzondere elegantie van het beeld en het feit dat het hoofd en de handen van de Bodhisattva ontbreken. Bij nader onderzoek naar de oorsprong van het beeld, de grotten van Tianlongshan, en de plaats van het beeld binnen die grotten, blijkt bovendien het belang van deze Bodhisattva voor onze kennis van de kunst en het religieuze leven van

U. China in de achtste eeuw.

\section{De grotten van Tianlongshan}

De grotten van Tianlongshan (ook wel T'ien Lung Shan of "de Berg van de Hemelse Draak") behoren tot de meest bekende, maar tegelijk ook meest afgezonderde grottempels van China. Ze zijn gebouwd op twee tegenover elkaar liggende bergwanden 40 kilometer ten zuidwesten van Taiyuan, de hoofdstad van de noord-Chinese provincie Shanxi. In de vallei tussen deze twee bergwanden bevindt zich de Shengshou tempel. Deze tempel dateert uit 560 en werd gebouwd door Gaohuan, de stichter van de Noordelijke Qidynastie (550-577). De oudste grotten gaan echter terug tot de Oostelijke Wei (534-550). Vergeleken met andere beroemde grottempels uit de periode van de Noordelijke- en Zuidelijke dynastieën (220-589) en de Tang-periode (618906), zoals Yungang en Longmen, is Tianlongshan wellicht kleiner van schaal. Er zijn in totaal 25 grotten. Kleinere nissen, zo talrijk in andere grottempels, ontbreken hier. Desalniettemin staat Tianlongshan voor een bijzondere verzameling beeldhouwkunst van verschillende perioden.

Afbeelding 1

Bodhisattva uit de grotten van Tianlongshan, zandsteen h. $95,0 \mathrm{~cm}$. China, begin $8^{e}$ eeuw Rijksmuseum, inv.nr. AK-MAK-75

\section{De Bodhisattva van het Rijksmuseum}

Ons beeld is een van zeven beelden uit grot 14, een van de vroege Tanggrotten. Het beeld stond tegen de rechterwand van de grot, links van de centrale Boeddha tegen de noordwand. Na een grondige reconstructie van de grot ${ }^{1}$ is gebleken dat het hoofd van dit beeld tegenwoordig onderdeel is van de collectie van het British Museum in Londen. ${ }^{2}$ De overige beelden van grot 14 zijn verdeeld over collecties in Zürich, Tokyo en Hartford.

De Bodhisattva van het Rijksmuseum is een vroeg voorbeeld van wat later zou uitgroeien tot de stilistische trend van de Tang dynastie: de zachte, ronde vormen van het beeld zijn tot in de details van de knieën en ellebogen uitgewerkt. Het gewaad van de Bodhisattva, een echt lijnenspel, lijkt gemaakt te zijn om dit nog verder te accentueren: de vloeiende bedekking van schouders en dijen doet denken aan de stijl cao yi chu shui. Deze stijl is vernoemd naar de zesde-eeuwse kunstenwaracao Zhongida: wients ${ }^{26 / 2023}$ 08:55:55 AM 
onderwerpen altijd net uit het water leken te zijn gekomen. ${ }^{3}$ Ook de sierlijke houding van de Bodhisattva, de lichte beweging naar links, geeft blijk van de hoge artistieke maatstaven die op dit beeld zijn toegepast.

Op grond van stilistische kenmerken hebben Vanderstappen en Rhie het beeld toegeschreven aan het jaar 725 . Echter, een bijzondere inscriptie uit grot 15 maakt ook een iets vroegere datering mogelijk, en doet bovendien explicieter recht aan de eigenlijke waarde van de Bodhisattva. Deze inscriptie uit $707^{4}$ is de enige inscriptie uit de Tang over de bouw van een grot in Tianlongshan. Het is tevens een van de weinige inscripties in Tianlongshan in het algemeen. De tekst vertelt het verhaal van een zekere Heichi, de vrouw van generaal Wubu Xuntong, die in 706 beelden van drie Boeddha's liet maken. Hiermee is een aanwijzing gegeven voor de bijzondere, maar vooral ook afgezonderde status van deze grottempels. Het gebrek aan teksten van andere donoren en het ontbreken van kleinere nissen van minder welgestelde individuen of religieuze organisaties (veelvuldig te vinden in de grottempels van Longmen of Dunhuang) doen vermoeden dat slechts keizerlijke of hooggeplaatste families betrokken waren bij de bouw en het onderhoud van Tianlongshan. De figuren in grot 15 zijn inmiddels ten onder gegaan aan erosie, maar Japans beeldmateriaal uit de jaren ' 20 van de vorige eeuw wijst uit dat deze beelden grote stilistische gelijkenis vertoonden met de beelden uit grot 14 , die waarschijnlijk omstreeks dezelfde periode zijn gemaakt. Door de inscriptie uit grot 15 uit 707 spelen de beelden in grot 14, en dus ook het beeld in het Rijksmuseum, een belangrijke rol bij het begrijpen van de motivatie achter en de datering van de overige beelden van Tianlongshan.

\section{Noten}

1. Harry Vanderstappen en Marylin Rhie, "The Sculpture of T'ien Lung Shan: Reconstruction and Dating", in: Artibus Asiae, Vol. 27 (1965), pp. 189-237.

2. Ibid., pp. 199-201.

3. Ibid., fig. 53.

4. Zie Li Yuqun, "A New Understanding of the Tang Dynasty Grottoes at Tianlongshan", in: Orientations, Vol. 34/5 (2002), pp. 48-53.

5. Ibid., fig. 8. 